Bond University ePublications@bond

Sports Law eJournal

Faculty of Law

$12-2017$

\title{
Regulating Discrimination in Sport: Mandatory Rules or Discretionary Guidelines?
}

Chris Davies

James Cook University, Australia

Follow this and additional works at: http://epublications.bond.edu.au/slej

Part of the Law Commons

\section{Recommended Citation}

Davies, C. (2017). Regulating Discrimination in Sport: Mandatory Rules or Discretionary Guidelines?. Retrieved from http://epublications.bond.edu.au/slej/32

This Journal Article is brought to you by the Faculty of Law at ePublications@bond. It has been accepted for inclusion in Sports Law eJournal by an authorized administrator of ePublications@bond. For more information, please contact Bond University's Repository Coordinator. 


\title{
Regulating Discrimination in Sport: Mandatory Rules or Discretionary Guidelines?
}

\begin{abstract}
Sport, like all industries, is subject to domestic discrimination legislation, which in turn is derived from international treaties. Many sports have also developed internal policies, regulations and/or guidelines to help with the governance of discrimination issues. The Australian Football League (AFL) has had to deal with a number of recent racist situations involving spectators. It is suggested that the AFL should consider implementing an anti-racism policy aimed at spectators like the one developed by the International Cricket Council (ICC). Netball's rules banning pregnant women from competing were held to be discriminatory and illustrate that guidelines providing recommendations can be a better solution for sports than mandatory rules or regulations. The case of Dutee Chand has meanwhile raised the question of whether women with naturally high levels of testosterone should be allowed to compete in women's events. The decision of the Court of Arbitration for Sport (CAS) that regulations banning her from competing were discriminatory again highlights that guidelines, rather than regulations, can be a better solution for sports. In 2008 the issue of potential disability discrimination was raised when double amputee sprinter, Oscar Pistorius, sought to compete, with the aid of artificial limbs, at the able bodied Olympic Games. While CAS determined it had not been proven that Pistorius had a net advantage, it is suggested that test should have been whether he ran differently to able bodied athletes.
\end{abstract}

\section{Keywords}

gender, disability, race

\section{Disciplines}

Law 


\title{
REGULATING DISCRIMINATION IN SPORT: MANDATORY RULES OR DISCRETIONARY GUIDELINES?
}

\author{
CHRIS DAVIES*
}

\begin{abstract}
Sport, like all industries, is subject to domestic discrimination legislation, which in turn is derived from international treaties. Many sports have also developed internal policies, regulations and/or guidelines to help with the governance of discrimination issues. The Australian Football League (AFL) has had to deal with a number of recent racist situations involving spectators. It is suggested that the AFL should consider implementing an anti-racism policy aimed at spectators like the one developed by the International Cricket Council (ICC). Netball's rules banning pregnant women from competing were held to be discriminatory and illustrate that guidelines providing recommendations can be a better solution for sports than mandatory rules or regulations. The case of Dutee Chand has meanwhile raised the question of whether women with naturally high levels of testosterone should be allowed to compete in women's events. The decision of the Court of Arbitration for Sport (CAS) that regulations banning her from competing were discriminatory again highlights that guidelines, rather than regulations, can be a better solution for sports. In 2008 the issue of potential disability discrimination was raised when double amputee sprinter, Oscar Pistorius, sought to compete, with the aid of artificial limbs, at the able bodied Olympic Games. While CAS determined it had not been proven that Pistorius had a net advantage, it is suggested that test should have been whether he ran differently to able bodied athletes.
\end{abstract}

\section{INTRODUCTION}

Discrimination, of all types, has been the subject of international treaties and domestic legislation, and now discrimination involving gender, disability and race is all considered to be unlawful. Sport, like other industries, is therefore required to abide by these laws, with sports governing bodies also having developed internal rules, regulations, policies and/or guidelines to assist in the governance of these discrimination issues.

This paper will examine a number of specific case examples which have raised issues relating to various areas of discrimination within sport. The first is the racism issues regarding the treatment of Sydney Swans star, Adam Goodes, by both spectators and officials. It will examine how the matter was dealt with by the AFL, and whether the AFL should adopt the ICC racism policies in regard to spectators. It will then analyse the legal consequences of netball's attempt to ban pregnant women from playing, and the contractual issues raised by women cricketers' contracts with Cricket Australia (CA). Finally, it will look at various areas of discrimination that have arisen regarding the Olympic Games, including disability discrimination, and the challenges arising from the participation of transgender and intersex athletes.

\section{THE ISSUE OF RACISM}

\section{A Adam Goodes and the AFL}

The AFL has a Member's Protection Policy in place, which seeks 'to promote... responsible behaviours within Australian Football. ${ }^{1}$ The AFL also has a National Vilification and Discrimination Policy, s 4 of which deals with vilification and discrimination, ${ }^{2}$ with the Policy also dealing with the process to be utilised when a complaint has been made. Conciliation is the first step, but if that fails to achieve a satisfactory outcome, an investigation can be made and it can also be referred to a disciplinary tribunal. ${ }^{3}$ While this has been considered a good model of how sports governing bodies should handle racism issues, and has proven to be successful in regard to incidents involving players, ${ }^{4}$ a number of incidents involving former Sydney

\footnotetext{
Associate Professor in Law, James Cook University.

AFL Member Protection Policy (June 2013), 3.

AFL National Vilification and Discrimination Policy, 5

Ibid 6-7.

Chris Davies and Neil Dunbar, 'The Internal Policing of the Enduring Issue of Racism in Professional Team Sports' (2015) 17

The University of Notre Dame Australia Law Review 59.
} 
Swans Indigenous star, Adam Goodes, have raised questions as to how effective the AFL policy actually is when spectators are involved.

One incident occurred during a match between Collingwood and Sydney on 25 April 2013 when a young girl called the Sydney Swans player, Adam Goodes, 'an ape.' The 13 year old later apologised to Goodes who 'explained to her why it deeply offended him,' though he also urged people to treat the girl with compassion, and because of her age, a deterrent penalty was not considered suitable. ${ }^{5}$ However, during an Essendon and Sydney game on 16 May 2014, an Essendon spectator referred to Goodes as a 'gorilla,' and was subsequently reported to security by another Essendon fan. The club appropriately evicted the offender from the ground and later suspended his club membership. ${ }^{6}$

Eddie McGuire, President of AFL club, Collingwood, meanwhile made a comment on Melbourne radio on 29 May 2013 stating that Goodes could perhaps be used to promote the musical, King Kong. While McGuire did offer an apology by means of a phone conversation with Goodes, this was only reluctantly accepted, ${ }^{7}$ though McGuire also agreed to undergo counselling. ${ }^{8}$ It is suggested that McGuire should have been suspended for a suitable period of time, possibly six months, from his position as President of Collingwood. ${ }^{9}$ Thus, the author considers that appropriate action by the AFL was sadly lacking in the McGuire case, certainly in comparison with how the National Basket Association (NBA) and the Football Association (FA) handled similar situations involving equally unacceptable comments by those holding powerful positions within a club. ${ }^{10}$

Even more disturbing, however, was the spectator reaction to Adam Goodes during the 2015 AFL season in the form of continuous booing whenever he was close to the ball. It reached an unacceptable level during the Round 17 match against the West Coast Eagles in Perth, Goodes then taking immediate leave from training and playing, fully supported by his club. He also received support from other clubs who wore their Indigenous Round jerseys for the following week's matches, with there being further shows of support throughout the AFL, no more so than at the Sydney Swans next home game against the Adelaide Crows at the Sydney Cricket Ground (SCG). The club put on a highlight package on the scoreboard screens just prior to the match, with the Swans cheer squad organising an English football style minute's applause at the seven minute mark of the third quarter, Goodes' playing number being 37. Before the game The Sydney Morning Herald had meanwhile produced a four page lift out in support of Adam Goodes. ${ }^{11}$

Goodes returned the following week and played out the rest of the season. However, there were further problems with crowd behaviour, such as the Preliminary Final against North Melbourne at ANZ Stadium. After that game Goodes announced his retirement, which he may well have done anyway, but there is still an element of doubt as to whether one of the most decorated players was pushed out of the game, for judging by his performances in his last few matches, he was certainly capable of continuing on for another season. ${ }^{12}$ What is definite is that spectator behaviour saw Goodes miss the traditional Grand Final parade for retiring players.

While the AFL community displayed strong support for Goodes, the AFL itself was slow to react to what became a rapidly deteriorating situation. Thus, while the AFL can claim to have an effective racism policy in regard to the players, it is suggested that it perhaps should also consider having a policy designed specifically for spectators, like the one developed by the ICC.

\footnotetext{
Adrian Crawford, 'Adam Goodes 'Gutted by Racial Slur but Wants AFL Fan Educated', ABC News (online), 27 May 2013 <http://www.abc.net.au/news/2013-05-25/goodes-gutted-but-places-no-blame/4712772>.

Peter Lalor, 'Goodes extends an olive branch to his taunter', The Australian, 23 May 2014, 35.

Melanie Dinjaski, 'Eddie McGuire Formally Apologises for Goodes' Radio Gaffe', Yahoo News, 29 May 2013 $<$ https://au.sports.yahoo.com/afl/a/17369360/eddie-mcguire-compares-adam-goodes-to-king-kong-on-radio/>.

8 Nathan Schmook, Eddie McGuire to Start Counselling over Racial Vilification (14 June 2013) <http://www.afl.com.au/news/201306-14/mcguires-counselling-to-start>.

9 Chris Davies and Neil Dunbar, 'The Internal Policing of the Enduring Issue of Racism in Professional Team Sports' (2015) 17 The University of Notre Dame Australia Law Review 59, 64.

10 Ibid 63-4.

11 See specifically Peter FitzSimons, 'Come back and play Adam, millions admire and support you', The Sydney Morning Herald 1 August 2015. See also Trent Dalton, 'Mob Rules', The Weekend Australian Magazine, 29 August 2015, 14.

12 Andrew Wu, 'Booing of Swans great “disgraceful” says Colless,' The Sydney Morning Herald, 21 September 2015, 34; Andew Wu, 'Goodes transcended sport into national consciousness", The Sydney Morning Herald, 21 September 2015, 34.
} 


\section{B The ICC Racism Policy}

Cricket is an international sport, primarily played in Commonwealth countries. With a diverse range of cultures and ethnical backgrounds it has had its share of racism issues, such as the claim that India's Harbhajan Singh had allegedly called Australia's Andrew Symonds a 'monkey' during the Second Test at the SCG on the 2007-8 tour, a comment that had racist overtones as Symonds is of West Indian descent. ${ }^{13}$ International cricket had also experienced problems with racial slurs from spectators, with South Africa's Andre Nel, for instance, reportedly being called a 'Kaffir lover' during an international match at the SCG in 2006, while other racial comments aimed at the South Africans were made at the WACA in Perth during the same season. ${ }^{14}$

The ICC therefore developed an Anti-Racism Code for Players and Player Support Staff, penalties for breaches being enforceable under contract law. In addition it also has an Anti-Racism Policy for International Cricket which is primarily aimed at spectators. The policy is expressly described in Clause 3 to 'complement the provisions' of the Player Code. Clause 9 provides a policy statement which spectators must be made aware of prior to, and/or during, all international matches. This policy statement specifically states that it is 'a breach of the terms and conditions of entry' to engage in conduct that 'is likely to offend, insult, humiliate, intimidate, threaten, disparage, vilify, or unlawfully discriminate between persons based on their race, religion, culture, descent, and/or national or ethnic origin. ${ }^{15}$ It goes on to state that spectators who breach this can be ejected from the ground, face possible future bans and possible criminal sanctions. These policies are then placed on signs near entrances at the major cricket grounds, ${ }^{16}$ as well as being displayed on the large scoreboard screens, if these are present at the grounds. ${ }^{17}$

It is suggested that effectively splitting the racism policies into two makes sense from a legal perspective, the reason being that enforcement comes from different areas of law. For players and player support personnel, as mentioned, it is through the contract, while ejectment and banning of spectators rely on the law of licence, ${ }^{18}$ and actual prosecution, on domestic criminal law. ${ }^{19}$ It is further suggested this model is one which should be considered for other sports that have experienced problems with racist comments or acts from spectators. It is clear that during the situation involving the spectators booing Adams Goodes the AFL was effectively inactive, and it is suggested a policy like that implemented by the ICC may have helped

13 Harbhajan was initially found guilty in a code of conduct hearing, and suspended for three tests matches by match referee, South African, Mike Procter. This then lead to a threat by India to abandon the tour of Australia, with the episode being dubbed 'Bollyline' by the media. See P. Lalor, 'Tour in doubt as Indians put up the shutters over racism conviction against Harbhajan', The Sydney Morning Herald, 8 January, 2008, 1; A. Brown and J. Pandaram, 'Indians may still quit tour- BCCI', The Sydney Morning Herald, 10 January, 2008, 31; M. Wade, 'Sparks fly, and India burns over Bollyline', The Sydney Morning Herald, 8 January, 2008, 35. In a subsequent hearing Justice Hansen reached the conclusion that it was not possible to establish exactly what had happened: Judgment of Justice John Hansen, 30 January, 2008, [50]. For further discussion see Chris Davies and Neil Dunbar, 'The Internal Policing of the Enduring Issue of Racism in Professional Team Sports' (2015) 17 The University of Notre Dame Australia Law Review 59, 68-9.

14 A Brown, 'Security on alert after racist yobs taunt Nel', The Sydney Morning Herald, 5 January 2006, 33. Note that the comments were in Afrikkan and were therefore made by South Africans rather than Australians.

15 This wording, it should be noted, reflects that of the United Nations' International Convention on the Elimination of All Forms of Racial Discrimination. This Convention was established in New York in March 1966, the Convention being originally signed by 87 parties, and subsequently ratified by 177 countries.

16 The author has personally seen them at the Sydney Cricket Ground during international matches, and also at Tony Ireland Stadium, Townsville when it has hosted Australia A and Australian Under 19 matches.

17 The author has personally seen this being done before the commencement of play at international matches at the Sydney Cricket Ground.

18 The authority for licence is Cowell v Rosebill Racecourse Co Ltd (1936) 56 CLR 605. In this case, Cowell had paid four shillings in order to attend a race meeting at the Rosehill Racecourse, but during the meeting he was asked to leave, and when he refused, was forcefully removed from the ground. He then claimed he had been assaulted, with the racecourse arguing that his licence to be on the premises had been revoked and therefore he had been trespassing. It was held by the High Court that the licence granted to Cowell only created a contractual right, not a proprietary interest in the land, Chief Justice Latham, at 616, pointing out that fifty thousand people paying money to watch a football match does not create fifty thousand interests in the ground, and even those who pay for reserved seating have only 'what could be called "a term of hours" in the seat.' Thus the licence granted to Cowell was therefore revocable as it merely permitted what otherwise would have been an invasion of the rights of the licensor, in this case, the owners of the racecourse. The licensee then becomes a trespasser once notice has been given countering the licence, and a reasonable time has elapsed for the licensee to withdraw from the premises.

19 It should be noted that as an international governing body the ICC obviously has no criminal jurisdiction. This is why the notices are written in such a way as if criminal charges are to be laid then the criminal law in the jurisdiction where the offence took place has to be enforced. 
prevent the situation getting out of control in the first place, and if it had not, then at least helped the AFL to be better prepared to deal with the situation.

If the AFL was to adopt such a policy it should contain a policy statement, like the ICC's, which should then be conveyed to spectators by means of being printed on the tickets, displayed on prominent signs, and/or repeatedly displayed on the scoreboards, as is required under Clause 10 of the ICC policy. It is suggested screening it repeatedly on the scoreboard prior to the game and during designated breaks is an easy and inexpensive way of conveying the message, and may have had an impact on the unacceptable spectator behaviour. It is further suggested that if the Adam Goodes situation had escalated any further, the AFL may have had to consider following European football's lead and play, or at least threaten to play, matches in closed stadiums. The policy could therefore contain a clause stating that the AFL reserves the right to play matches in closed stadiums if there is ever repetitive, unacceptable behaviour from spectators that has a racist element to it.

While racism is an area of discrimination that is frequently highlighted in sport, another area that has raised legal issues is that of pregnancy, both in regard to participation in sport and the contractual terms of professional contracts.

\section{PRegnancy AND SPORT}

Discrimination against pregnant woman is prohibited by the Sex Discrimination Act 1984 (Cth), specifically s 7 and s 22, with this being an issue in Gardnerv All Australia Netball Association Ltd. ${ }^{20}$ Trudy Gardner was the captain of the Adelaide Ravens in the Commonwealth Bank Trophy, a national competition organised by the All Australian Netball Association (AANA). On 18 June 2001, the AANA imposed a ban on pregnant women from playing in the competition, and Gardner, who was 15 weeks pregnant at the time, was prevented from playing three matches between that date and 13 July. ${ }^{21}$ On 18 July Gardner obtained an injunction which allowed her to resume playing. ${ }^{22}$

When the matter eventually went to trial, the first issue was whether the exemption in s 39 of the Act applied. Section 39 states that it is not unlawful for a voluntary body to discriminate against members on various grounds, including pregnancy. It was accepted by the AANA and the relevant member and the South Australian Netball Association (SANA) were voluntary bodies. It was held, however, that Gardner 'was not and never could have been a member of the respondent [AANA].' 23 Thus, the conduct was not exempted under s 39, with it then being held that Gardner had been discriminated against, pursuant to ss 7 and 22 of the Act, by being prevented from playing in those three matches. Damages of $\$ 6750$ were therefore awarded. ${ }^{24}$

After Gardner the Australian Sports Commission (ASC) produced guidelines in regard to pregnant women in sport, ${ }^{25}$ with the decision to compete or not being left to the individual, with medical advice being recommended. It is suggested that while the original idea to prevent pregnant women from playing was well intended, what was required was a consultation process to develop a policy acceptable to both players and officials, which was achieved after the case. It should also be noted that Gardner had sought medical advice when she had discovered she was pregnant on 8 May 2001, firstly from her General Practitioner, then from an obstetrician she was referred to. The medical advice was that there was no medical reason preventing her from playing netball at her stage of what was a healthy pregnancy. ${ }^{26}$ Note that the ASC guidelines had in effect been followed by Gardner prior to their existence, and it is suggested one of the outcomes of the case is that it illustrates guidelines providing recommendations can produce a more productive outcome than mandatory regulations, particularly as the later may be in breach of domestic discrimination legislation.

One of the most significant aspects of sport in 2017 has been the success of women's leagues and competitions. The gold medal win by the Australian women's rugby sevens team at the 2016 Rio Olympic

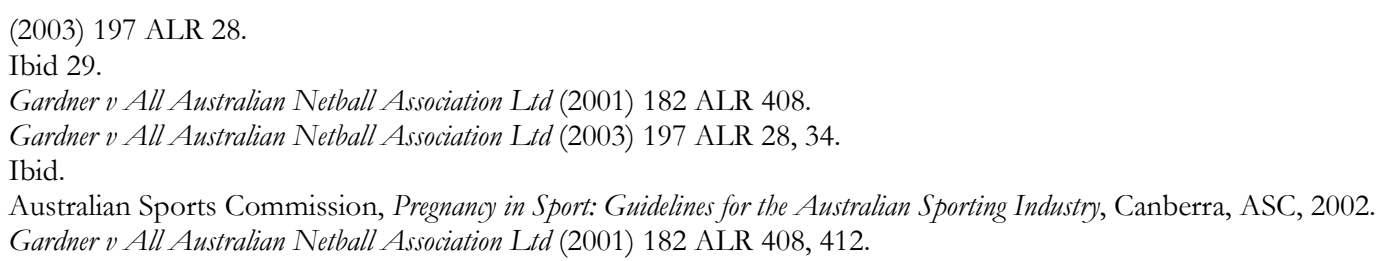


Games gave them a higher profile in the already existing world sevens competition. The AFL women's league was a major success in its first season, while the Women's Big Bash League was just as successful in what was its second season. However, the contracts CA has with the women players that has raised some legal concerns.

The clause in question relates to the requirement that the players inform CA that they are pregnant. This raises the issue as to whether this is discriminatory, or merely involves an employer needing to know about a matter involving potential workplace health and safety issues as a pregnant woman being hit by a cricket ball certainly has potential safety issues. It is suggested that the torts issue is the same as that of netball, which indicates that the guidelines CA should apply are to recommend medical advice. The contractual issue arises from CA asking a player to state, as a term of the contract, whether or not they are pregnant. The legal question is whether or not this is discriminatory, and if so, it is void as a contractual term. While the legislation is clear that discrimination based on pregnancy is unlawful, it is suggested that merely asking a player to state whether they are pregnant is not, in itself, discriminatory. However, it is suggested that any governing body, like CA, should first engage in a full consultation process with the players, and that there should also be what amounts to a confidentiality clause, that, for instance, requires that the player only needs to disclose, at least in the first instance, to an approved medical doctor.

It is further suggested that with this increase in the number of women playing professional sport, especially in the heavier contact sports of Australian football and rugby union, the legal issues arising from pregnancy are yet to be fully determined, though the lesson from netball's experience is that guidelines, rather than mandatory rules, are the best option. While the issue of pregnant players may provide a specific example of discrimination, what will now be examined is the much broader issue of discrimination within the Olympic movement, including that of gender.

\section{DisCRIMINATION AND THE OLYMPIC GAMES}

\section{A The IOC Policy}

It should be noted that under the Fundamental Principles of Olympism outlined in the Olympic Charter, any form of discrimination based on 'race, religion, politics, gender or otherwise is incompatible to the Olympic Movement. ${ }^{27}$ Under the Mission and Role of the IOC, it is stated that one of the roles of the IOC is 'to act against any form of discrimination affecting the Olympic Movement. ${ }^{28}$ Racial discrimination is therefore not permitted under the Olympic Charter, and to be fair, the Olympic Games itself has been free of racism, even though it has to be acknowledged that over the decades it is highly likely athletes have been left out of their country's Olympic team on the basis of race. However, there have been potential issues regarding other areas of discrimination, and what will now be examined is the historical question as to whether there was actually class discrimination within the Olympic movement.

\section{B Class Discrimination and the Olympic Games?}

While class discrimination is not specifically mentioned in the Olympic Charter, it is suggested that it could perhaps fit into the 'otherwise' category mentioned in the Fundamental Principles of Olympism. It should also be noted that when the modern sports began to become organised during the nineteenth century a strict amateur rule was often implemented, though this should be considered more as an instrument of class warfare than a real desire to prevent payments to participants. For instance, in the 1895 rugby union split the immediate conflict was over the rigid amateurism of the Rugby Football Union. The deeper disagreement, however, was on the nature of sport as a social institution, and as Guttman points out ${ }^{29}$, the bitterness of the controversy was derived largely from upper class and upper middle class fears that 'their' game was falling into the hands of lower class elements, particularly in the industrial north of England.

This ideal of amateurism then found its way into Baron Pierre de Coubertin's dream of reviving the spirit of the Ancient Greeks with a modern version of the famous Games, and at the Sorbonne Congress in June 1894, Coubertin's prevailing view was that only amateur sport was clean, and that professional sport turned

\footnotetext{
Olympic Charter, 11

Ibid 14.

29 Ibid 31.
} 
'superior athletes into circus performers.' This view was popular amongst many of the aristocratic elite who dominated the early years of the IOC, not because they necessarily agreed with it, but because it consolidated their power base in the fledgling organisation. ${ }^{30}$ Amateurism, therefore, was to become the entrenched doctrine within the Olympic movement for the best part of a century. The length to which this amateur rule in Olympic sport was implemented can be seen in the decision to disqualify 1908 silver medallist in swimming, Australian Frank Beaurepaire, from the 1912 Stockholm Olympic Games because he held down a job as a physical instructor, enough in those class riddled days to be classified as a 'professional'. After these Games, United States athletics star, Jim Thorpe, was stripped of the gold medal he had won in the decathlon when it was later found he had, unwittingly, played semi-professional baseball.

Amateurism, therefore, became the entrenched doctrine of the Olympic movement until it was abandoned in 1984. ${ }^{31}$ This meant the modern Olympics had finally returned to what they had been in Ancient Greece: a prestigious 'amateur' event, since no prize money was on offer, but one for professionals as Ancient Greek athletes competed for considerable prize money at other Games, and were often supported by the state.

Thus, while what could have been considered class discrimination is no longer an issue with the Olympic movement, but it perhaps can be viewed as an example of what could fit into the 'otherwise' component in the Olympic Charter. While this is perhaps arguable, which is clear is that the Olympic Charter expressly prohibits discrimination based on gender.

\section{Gender Discrimination}

While the fact that women were not allowed to attend the Ancient Olympic Games, appears, prima facie, to be sexist, what has to be kept in mind is that those Games originated from a much earlier religious ceremony that was restricted to males. Indeed one of the seven wonders of the ancient world was the great statue of Zeus at Olympia, the site of the Ancient Olympic Games. Women, however, had their own religious ceremonies and also had their own athletic competitions, such as the Heraean Games. ${ }^{32}$ Sport in Ancient Greece was therefore more segregated than discriminatory.

However, when the Olympic Games were to be revived, Baron de Coubertin, opposed female participation in the Olympic Games. There were, therefore, no women's events at the First Modern Olympic Games of 1896, and only women's tennis was included in the 1900 Paris Olympic Games. Women's swimming made its debut in 1912, while the prestigious athletics programme did not have any women's events until 1928.33 Changing social attitudes regarding the role of women, particularly in western countries, gradually resulted in more women's events being added to the Olympic programme, though it should be noted that the women's programme at the 2016 Rio Olympic Games still had 21 less events than the men's.

Thus, the Olympic Charter now ensures that gender discrimination is not allowed at the Olympic Games. However, what has become clear is that the issue of gender is not as clear as dividing everyone into males and females, which raises the question as to whether transgender and intersex athletes should be allowed to compete in women's events.

\section{The Issue of the Participation of Transgender and Intersex Athletes}

Transgender is a term that can be applied to athletes who have undergone sex-change operations, such as tennis player, Renee Richards. Richards was originally Richard Raskind who had played professional men's tennis before undergoing sex reassessment surgery in 1975. The United States Tennis Association (USTA) then banned Richards from playing on the women's professional circuit on the grounds she had a competitive advantage because of the physical development and training before the surgery. Richards

R. Mandell, The First Modern Olympics (University of California Press, Berkeley, 1976) 88.

Note than in 1984 the IOC also acknowledged past mistakes and, for instance, returned Jim Thorpe's gold medal to his children.

A. Guttnam, From Ritual to Record: The Nature of Modern Sport (Columbia University Press, New York, 1978) 28.

Note that Guttnam suggests this prejudice against women may have been derived more from Victorian attitudes about 'porcelain-doll femininity', and therefore was not so much a result of direct hostility against women as over protectiveness: See Guttnam, above n 32, 34. 
challenged the ruling in court where it was held that the USTA was misdirected in their fears and its reasons for the ban were not supported by medical evidence. ${ }^{34}$

While the Richard's case involved actual gender changing surgery, other cases have highlighted intersex issues of female athletes having, for instance, naturally high levels of testosterone, and whether they should be allowed to compete in female competitions. South African middle distance runner, Caster Semenya, for example, was ordered to undergo sex tests after winning the $800 \mathrm{~m}$ at the 2009 World Athletics Championships. She was allowed to compete at the 2012 London Olympic Games where she won the silver medal, before winning gold at the 2016 Rio Olympic Games. It was a controversial win by an athlete considered by those in the sport to be intersex with a higher than normal testosterone level. ${ }^{35} \mathrm{After}$ her win, the International Association of Athletic Federations (IAAF) President, Lord Sebastian Coe, announced that the organisation would be looking at taking the matter of hyperandrogenic competitors back to CAS in 2017.36 The reason for this is to overturn the accepted precedent for the case ${ }^{37}$ involving Dutee Chand, an Indian sprinter, who also competed at the 2016 Rio Olympic games..$^{38}$

Dutee Chand was, at the relevant time, a 19-year-old sprinter of Indian nationality who was banned under the IAAF's Regulations Governing the Eligibility of Females With Hyperandrogenism to Compete in Women's Competition (the 'Regulations). ${ }^{39}$ Chand was then banned from the 2014 World Junior Championships, and on 31 August 2014, was declared ineligible to compete in any athletic competition. ${ }^{40}$ The subsequent CAS challenge was on the grounds that the Regulations discriminated against female athletes possessing particular natural physical characteristics as they were based on flawed factual assumptions regarding the relationship between testosterone and athletic performance. As the CAS Panel noted, the case 'raises complex legal, scientific, factual and ethical issues. ${ }^{41}$ From an evidentiary perspective, Chand had to prove the Regulations were prima facie discriminatory, ${ }^{42}$ and if so, the IAAF had to prove, on the balance of probabilities, they were justifiable as being reasonable and proportionate. ${ }^{43}$

Extensive expert evidence was produced by both parties, with Dr Karkazis, on behalf of Chand, for instance, pointing out it was unfair to treat endogenous testosterone any differently to other physical variations that may affect athletic performance. Dr Karkazis also noted that it was poor women from the Global South who appeared to be the population most affected by the Regulations. ${ }^{44}$ A number of former athletes were also called as witnesses, with Madeleine Pape, an Australian 800m Olympic athlete, pointing out sports were inherently unfair due to factors such as differences in height and weight, and access to facilities and training. 45

The CAS Panel held that the Regulations were discriminatory, ${ }^{46}$ with the IAAF then having the burden to establish the Regulations were reasonable and proportionate to achieve their legitimate objectives. ${ }^{47}$ These were to 'provide for fair competition and a level playing field within the female category, and protect female athletes from having to compete against other athletes who enjoy a competitive advantage. ${ }^{4} 48$

It was stated by the CAS Panel that it was unable to conclude the Regulations fulfilled their stated purpose, but acknowledged that this may be due to sufficient data not yet being available. ${ }^{49}$ However, 'on the evidence

34 Renee Richards v The United States Tennis Association [1977] 400 NYS 2d 267 cited in David Thorpe, Antonio Buti, Chris Davies, Saul Fridman and Paul Jonson, Sports Law (Oxford University Press, 2 ed, 2013) 614.

35 Nicole Jeffrey, 'Gender Games', The Australian, 17 August 2016, 31.

36 Nicole Jeffrey, 'Coe fights to shut Caster loophole,' The Australian, 22 August 2016, 31.

37 Note that CAS, while it does not set binding precedents, makes it clear that it attempts to be consistent with previous decisions:

38 CAS 2014/A/379 Dutee Chandv Atbletics Federation of India \& International Associations of Athletic Federations. Note that a feature of the case is the length of the judgment since, at 160 pages, it is around four times the CAS average which reflects the complexity of the case.

39 Ibid [4].

40 Ibid [374]

41 CAS 2014/A/379 Dutee Chand v Athletics Federation of India \& International Associations of Atbletic Federations [374].

42 Ibid [450].

43 Ibid [443].

44 Ibid [251].

Ibid [353].

46 Ibid.

Ibid [501].

8 Ibid [508].

49 Ibid [531]. 
currently before it', the Panel was 'unable to conclude androgen-sensitive hyperandrogenic female athletes enjoyed such a substantial performance advantage over non-hyperandrogenic female athletes that excluding them from competing in the female category', unless they undertook medication or treatment, 'is necessary and proportionate means of preserving fairness in athletic competition. ${ }^{50}$

Thus, while CAS acknowledged that higher levels of naturally occurring testosterone may increase athletic performance, it was not satisfied it was more significant than any other variable, such as biological factors and access to training facilities and coaching. ${ }^{51}$

The CAS Panel also went on to state that the IAAF had acted 'with conspicuous diligence and good faith' throughout the process of developing the Regulations. ${ }^{52}$ However the outcome of the CAS verdict was that the Regulations were suspended for two years, with the Panel stating that if the IAAF did not produce evidence supporting the magnitude of the performance enhancement within that period' the Regulations were to be declared void. ${ }^{53}$

This led to the announcement in early 2016 that transgender athletes may be allowed to compete at events, such as the Olympic Games, without the need to undergo sex reassignment. The reason stated for this was to adopt policies to 'current scientific, social and legal attitudes on transgender issues,' though what the policy provides are guidelines, rather than rules or regulations. If the IOC formally approves the recommendations, a female to male transgender may be allowed to compete immediately, while a male to female may need to show that their testosterone levels have dropped to an approved point for at least a year. ${ }^{54}$ However, there is no question that the issue of intersex athletes is far more complicated, and one that is likely to be a continuing controversial issue.

It should be noted that the consideration of the Paralympics is now stated in the Olympic Charter as being part of the process for the selection of the Olympic city, and over the last few decades cities have had to include the Paralympics in their bid. Since 2008 issues have also arisen regarding the participation of disabled athletes at the able bodied Games.

\section{E Disability Discrimination}

At the 2008 Beijing Olympic Games, South African swimmer, Natalie du Toit, who had lost the lower part of her leg in car accident when she was 17, competed in the Women's $10 \mathrm{~km}$ swimming event, where she finished a creditable sixteenth. ${ }^{55}$ While her participation indicates there is no discrimination at the Olympics in regard to disability, a significant factor was that she did not have to make use of any artificial limbs. Thus, du Toit illustrates that athletes with disabilities can compete in the able bodied Games, and to deny them could be in breach of the Olympic Charter as it is suggested that disability discrimination clearly could fit into the 'otherwise' provision. In fairness to the Olympic movement, as the du Toit case illustrates, there is no indication a disabled athlete with no reliance on artificial limbs, would ever be denied entry to Olympic competitions should they qualify. Where the issue arises is when a disabled athlete qualifies, but only with the aid of technology, as was the case with South African double amputee sprinter, Oscar Pistorius.

Pistorius was born on 22 November, 1986, without fibula bones in either of his lower legs, and as a result, he had both legs amputated below the knees when he was eleven months old. ${ }^{56}$ To participate in sporting events he used a prosthesis known as the Cheetah Flex-Foot, ${ }^{57}$ but in January 2008, the IAAF stated that he was in violation of Competition Rule 144.2(e) by using these in races. ${ }^{58}$ This particular rule prohibited the use 'of any technical device that incorporates springs, wheels or any other element that provides the user with an advantage over another athlete not using such a device.' It was also noted by the CAS Panel that it

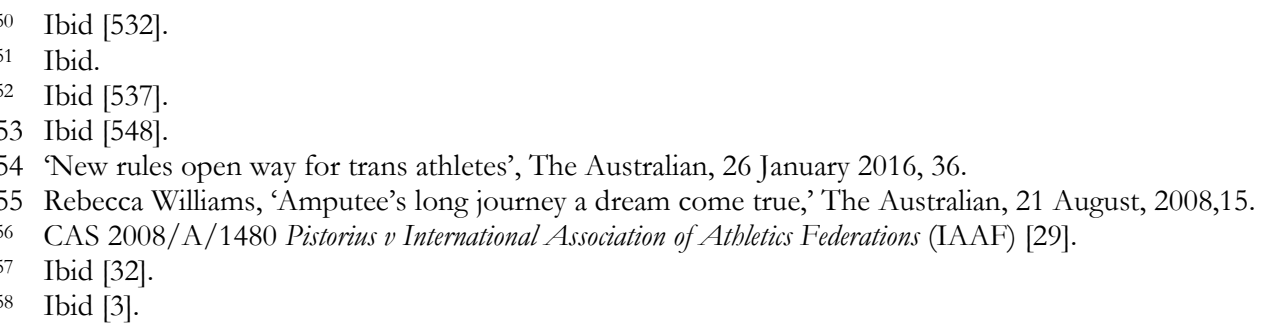


was likely that the new rule had been introduced with Pistorius in mind, and that it had started a process which led to him being declared ineligible to compete in IAAF sanctioned events. ${ }^{59}$

This IAAF ruling had come about after it had carried out tests at a special $400 \mathrm{~m}$ Golden Gala event in Rome which was videotaped by sports scientists. ${ }^{60}$ The analysis of the videotape indicated that Pistorius' stride length and the time his legs were in contact with the ground were significantly different to that of the able bodied runners. ${ }^{61}$ An evaluation of the race also indicated that Pistorius was slower out of the blocks than the other runners, and unlike the other runners, ran his fastest splits in the second and third 100 metres. Further tests were then carried out at Cologne by sport scientists in order to further evaluate Pistorius' sprint movements, with these being measured against five able bodied athletes of similar sprinting ability. ${ }^{62}$ The results of the tests were that Pistorius' Vo2 uptake was 25\% lower that the able bodied athletes while the energy return was clearly higher in the prosthesis than in the human ankle joints. These results, the scientists concluded, had given Pistorius significant biomechanical advantages. It was also concluded that running using the prosthesis involved 'a different kind of locomotion' ${ }^{63}$ when compared the motion of an able bodied athlete. After he was declared ineligible to compete in IAAF sanctioned events, Pistorius appealed to CAS.

CAS examined whether the IAAF decision was wrong in concluding that Cheetah Flex-Foot device was in breach of Rule 144.2(e), with it being noted convincing scientific proof that it provided him with an overall advantage was required. CAS also noted that it was possible the use of such a device could actually provide more disadvantages than advantages, which therefore meant that it could not be reasonably said that it provided an advantage over other athletes as the user could be at a competitive disadvantage. ${ }^{64}$

Since the IAAF had not asked the sport scientists involved in the tests to determine whether the prosthesis had provided an overall net advantage, it had not proved, on the balance of probabilities, that Rule 144.2(e) had been breached. ${ }^{5}$ This was because sport scientists did not know whether the creation of more vertical force by able-bodied athletes provides an advantage or disadvantage, with evidence being accepted that a $400 \mathrm{~m}$ runner may actually train themselves to bounce more, that is, create more vertical force since this will create more speed. This meant that Pistorius may be at a disadvantage, rather than at an advantage. ${ }^{66}$

It was also noted that the Cheetah Flex-Foot had been used by other athletes for many years, and as these athletes had not come close to matching the times run by Pistorius, they were accepted as acting as an effective control for a study of the benefits of using the prosthesis, and demonstrated that any advantage may well have been 'quite limited. ${ }^{\prime} 7$ The CAS Panel then emphasised that it was possible improvements in scientific testing could mean that the IAAF would one day be able to show that the existing model did in fact give Pistorius an overall net advantage over other athletes. ${ }^{68}$ CAS also stated that the decision in this case had no application over other athletes, or other types of prosthetic limb, with each case needing to be considered by the IAAF on its own merits. ${ }^{69}$

The CAS decision was therefore decided on the technological aspects of the case, but it should be noted that one of Pistorius' claims was that the IAAF decision was discriminatory, and that the IAAF had denied him fundamental human rights, including an equal access to 'Olympic principles and values. ${ }^{{ }^{70} 0}$ It was held, however, that the relevant substantive law for the case was that of Monaco, as outlined in Article 16 of the IAAF Constitution rule, ${ }^{71}$ with CAS noting that Monaco had not ratified the United Nations' Convention on the Rights of Persons with Disabilities and its Optional Protocol that had been adopted on 13 December,

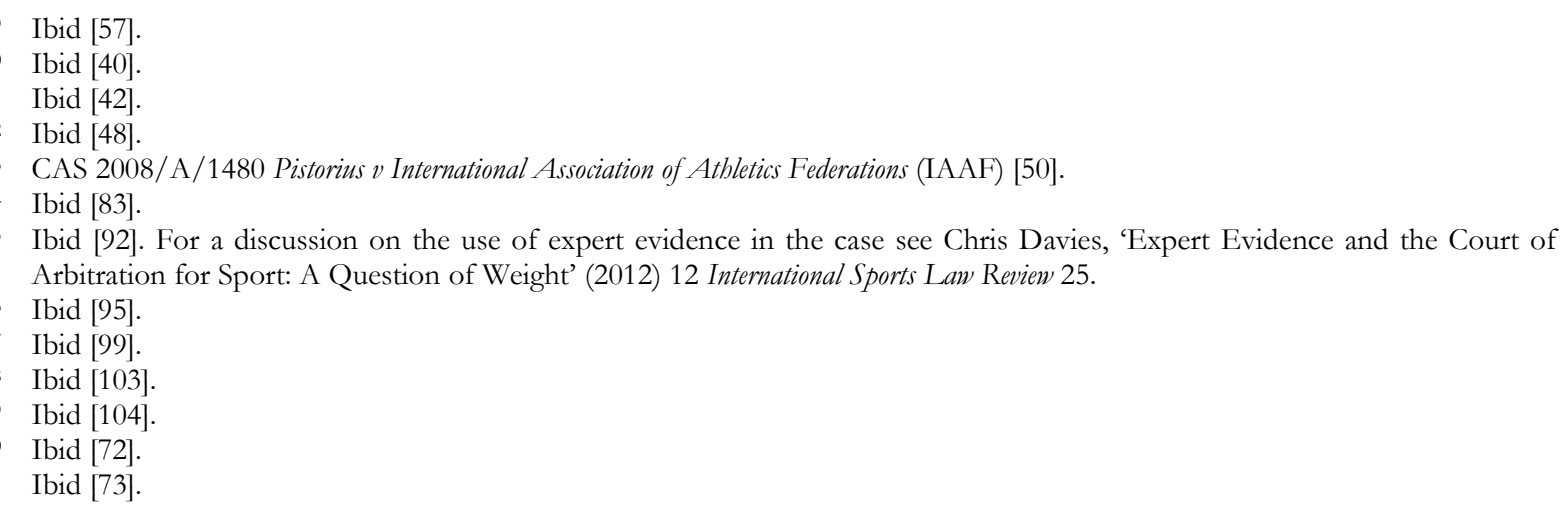


2006. ${ }^{72}$ However, it was held that the disability laws only require that an athlete such as Pistorius be permitted to compete on the same footing as others. This was precisely what CAS was being asked to decide in the case, and therefore, if the finding of CAS was that he did gain an advantage, the Convention would not help his case. For this reason the submission based on unlawful discrimination was rejected. ${ }^{73}$

The CAS decision meant that once he qualified Pistorius was eligible to compete at the 2012 London Olympic Games, where he was moderately successful. Fortunately in some ways, since it is unlikely either the IOC or the IAAF wanted to see a double amputee, using artificial limbs, sprinting home to win a medal. Pistorius' participation also attracted comments from experts that the IAAF could now most likely provide evidence to show that a disabled athlete like Pistorius do gain an advantage in certain aspects of a race. Thus, Pistorius may prove to be a one off situation, with even the CAS Panel acknowledging that the history of the Pistorius case was 'remarkable and without precedent. ${ }^{74}$ CAS also suggested that making decisions and carrying out acceptable tests in regard to artificial limbs was 'just one of the challenges of $21^{\text {st }}$ Century life. ${ }^{75}$ It is suggested, however, it would not be if the IAAF only had to prove that athletes like Pistorius ran with different biomechanics than able bodied athletes. It is also the author's opinion that this is all it should have to prove, and arguably already has, since there is sufficient evidence provided in the Pistorius case to support this. ${ }^{76} \mathrm{It}$ is further suggested that despite CAS deciding in favour of Pistorius there are sufficient statements within the judgment to indicate that the IAAF, and potentially other international governing bodies, could successfully exclude disable athletes competing with the aid of artificial limbs in able bodied events.

\section{CONCLUSION}

Discrimination is unacceptable in sport, as it is in general life, with the legal basis of this being established in international treaties and domestic legislation. It is also reflected in the internal policies and regulations of many sports. However, as Gardner clearly illustrates, these policies and regulations must operate within the limits of discrimination legislation. This case, like Chand, also highlights that guidelines providing recommendations can be more efficient as internal policies than mandatory regulations. The ICC's racism policies, involving one for players and support staff, and another for spectators, have a sound legal basis to it due to different law being needed to enforce them. It is also suggested that after the situation involving Adam Goodes, the AFL should perhaps consider having a similar spectator racism policy. While the IOC has clear policies, it has had to deal with the issues of whether disabled and intersex athletes should be allowed to compete at the Olympic Games, both of these being potential issues in the years to come.

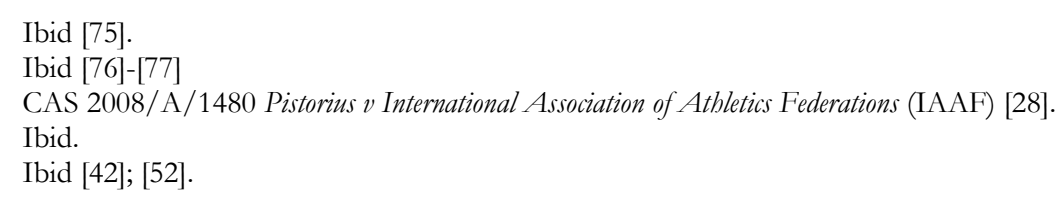

